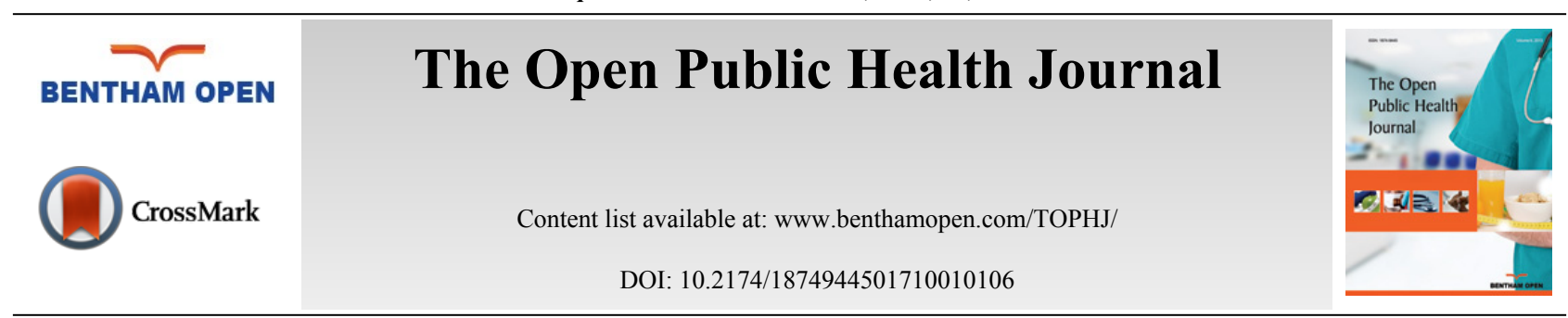

RESEARCH ARTICLE

\title{
From Pastoral Care to Public Health: An Ethnographic Case Study of Collaborative Governance in a Local Food Bank
}

\author{
Geoffrey Meads* \\ Health and Wellbeing Research Group, University of Winchester, Winchester UK
}

Received: January 04, 2017

Revised: February 28, 2017

Accepted: March 14, 2017

\begin{abstract}
:
Background:

Escalating urgent demand for subsistence, especially from young families, has been matched by the rapid increase in food bank outlets in the United Kingdom. The majority of these have originated in faith based initiatives, initially through small back street service outlets and, more recently as frontline social enterprises contributing nationwide to social security and welfare provision.
\end{abstract}

\section{Objective:}

The article seeks to describe, define and discuss developments in collaborative governance from 2006 to 2016 in a local food bank. An established analytical framework for community services is applied to identify implications for public health.

\section{Method:}

An ethnographic approach is employed. Data sources include structured research diary notes, agency agendas, local surveys and stakeholder workshops, and participant observation. Key events are identified through five yearly time interval assessments of critical decision making between 2006 and 2016.

\section{Results:}

The local narrative indicates a progression towards wider representation in the collaborative governance arrangements, with a corresponding advance in awareness of food poverty and public health issues. Initially neglected, these emerge with the changes in organisational status from informal volunteers group to complex formal organisation with specialist management functions. Increases in scale and differentiation also apply to the broader profile of Christian agencies and shift towards control by those with stronger physical and institutional structures. However, although the local service has helped raise awareness of food poverty in civic agencies, scriptural sources remain more influential than secular strategies.

\section{Conclusion:}

The local food bank experience points to basic changes in the relationship between church and state in social welfare, and highlights the challenge for faith based social enterprises of representing effectively increasingly diverse communities. For public health, led by elected Councils, there are opportunities to harness new resources and enhance public trust.

Keywords: Governance, Food bank, Faith, Collaboration, Food poverty, Social enterprise.

\section{CONTEXT}

In the United Kingdom, food banks began to operate in the mid-1990s as a charitable source of assistance for those - such as newly discharged prisoners, recovering drug addicts or homeless persons - who were in urgent need of subsistence support. They were originally intended to supplement the State's national welfare system by, for example

* Address correspondence to this author at the University of Winchester, Health and Wellbeing Group, Sparkford Road, Winchester, SO22 4NR. UK, Tel: 01962 826364; E mail: geoffrey.meads@winchester.ac.uk 
making provision when such social security payments as unemployment benefits were delayed. Food was supplied by the banks on the basis of written referrals from local 'partner' health and social care agencies, which formally assessed and endorsed the level of need. This usually led to provision of a week's food supply on a case-by-case basis. The food at a food bank was 'deposited' through donations from local people individually and collectively, including both commercial companies and Christian churches.

Since their inception two decades ago, food banks have increased rapidly in number and become established as core components in the provision of social security within the United Kingdom (UK). Already by 2013, in the relatively affluent southern English county of Hampshire, with its population of just under two million people [1], there were then, at least, 33 food banks in operation [2], excluding collection points. Moreover, a number of these now operate increasingly through strategically dispersed service outlets with, for example, a total of four local neighbourhood sites opening for a minimum of one day per week in 2016 across the Winchester district. This last has a population of 120000.

The vast majority of food banks have originated in faith based local initiatives. Of these, the most significant has been the Trussell Trust with over 400 food banks in 2014/2015. This charity was founded in Salisbury, Wiltshire, in 1997 and extended nationally, as a social enterprise, through the adroit use of different church and parish networks in response to escalating demand [3]. While this Trust has Christian roots, others have been supported by other religions with, for example, the national Islamic leadership citing the 1.5 million UK pensioners believed to be in food poverty, in support of the Muslim Food Programme's stated aim: 'to spread mercy to humanity irrespective of colour, gender, creed or political affiliation' [4]. While all food banks have referral criteria defined in terms of urgent need, none are discriminatory in relation to specific population groups.

The perceived need for food banks has continued to grow. In 2014/2015, the Trussell Trust gave out 1,084,604 three day emergency food supplies [5]. As the Trust operates around half of all food banks, and many of the others provide five day subsistence packages as their staple offer, it seems likely that the national UK total is now around seven million meals per annum. The Winchester Basics Bank - so named because it has also supplied some clothing, cosmetics and bedding - is one of those which makes the five day offer.

The growth in both supply and demand has significantly changed the context. Food banks are now perceived to be a political issue. As such, they engage those with responsibilities for social policy and public health. Major nongovernmental charities with a global reach have decried the 'scandal of food poverty in the twenty first century UK' [6]. An All Party Parliamentary Group has been convened with Members of Parliament co-chairing from across the main political divide (Frank Field, Labour, and Laura Sandys, Conservative); and the House of Commons has issued its own report confirming that, overwhelmingly, food banks are a response to genuine social need [7]. In Hampshire, the changing context has led to commissioned research which has addressed the future sustainability and resourcing of food banks. While these studies have included recommendations to improve the targeting of food aid [8], a principal focus has been on collaborative governance arrangements: the sharing of data, planning with statutory welfare agencies, contributing to 'wider networks of social support' and, increasingly, helping to tackle public health issues arising from poor diet and shortfalls in nutrition [9].

\section{PURPOSE}

The first aim of this article to draw on a public health context to describe, define and discuss the changes in collaborative governance in a local food bank over a ten year period between 2006 and 2016, during which time it moved from the status of a small church volunteers group to that of a sizeable and community based social enterprise. The account provided in this article adopts a longitudinal study perspective, and is designed to be illustrative of parallel and subsequent changes in governance being experienced by other services originating in faith based settings. These now include, inter alia, Street Pastors, Good Neighbour Support schemes and, in the Winchester Diocese, new 'Launchpad' facilities of pre-school centres and children's nurseries [10].

Given the innovative status of many of these developments there is a perceived need for transferable learning - from such as the food bank experience - into these social enterprises. Responding to this need is the second aim of this research. In the first instance it looks to inform the Winchester Diocese's and City Council's current strategic plans for both social transformation and enhanced health and wellbeing $[11,12]$ by, for example, providing an empirical basis for voluntary sector grant funding decisions and the commissioned service specifications of community health agencies. The novelty of a new mixed economy of public health related interventions suggests, however, that this need for such 
transferable learning is felt well beyond the boundaries of a Hampshire district.

\section{RESEARCH PROCESS}

The period of participant observation and data capture upon which this study is based was from November 2006 to October 2016. During this ten year time period the author was involved continuously with the direct delivery of local food bank services in Central Hampshire in the roles of trustee, manager and volunteer. These positions have meant being embedded in the culture of local partnerships between faith based residential and research groups, each committed to the promotion of community health and wellbeing. Accordingly, the approach is ethnographic through cultural immersion over an extended timescale, with conversations and events recorded through regular diary notes and formal meeting agendas and minutes. This data capture has been augmented by further relevant documentation that includes Annual General Meeting reports and Away Day reviews, plus the results of internal client and volunteer surveys and, latterly, two stakeholder workshops convened in October 2015 and October 2016 in conjunction with the local authority and Food Up Front research charity. The last two agencies have also supplied relevant policy documents and procedural sources for the study.

The data capture and initial analysis for this social research has been structured by a framework for Collaborative Governance endorsed by the World Health Organisation and derived from an international evidence synthesis of research and practice developments in the non-statutory community health sector [13]. Its use in identifying 'Ideal Type' models for transferable learning has been established elsewhere in relation to the growing diversity of public health oriented primary and community care agencies [14]; into the membership of which grouping it is now appropriate to include food banks. Accordingly, the selected framework has allowed the accumulated data to be classified under the 'Ideal Type's five sub-headings of Information Sharing, Consultation, Involvement, Partnership and Empowerment [13]. These are set out below in (Fig. 1).

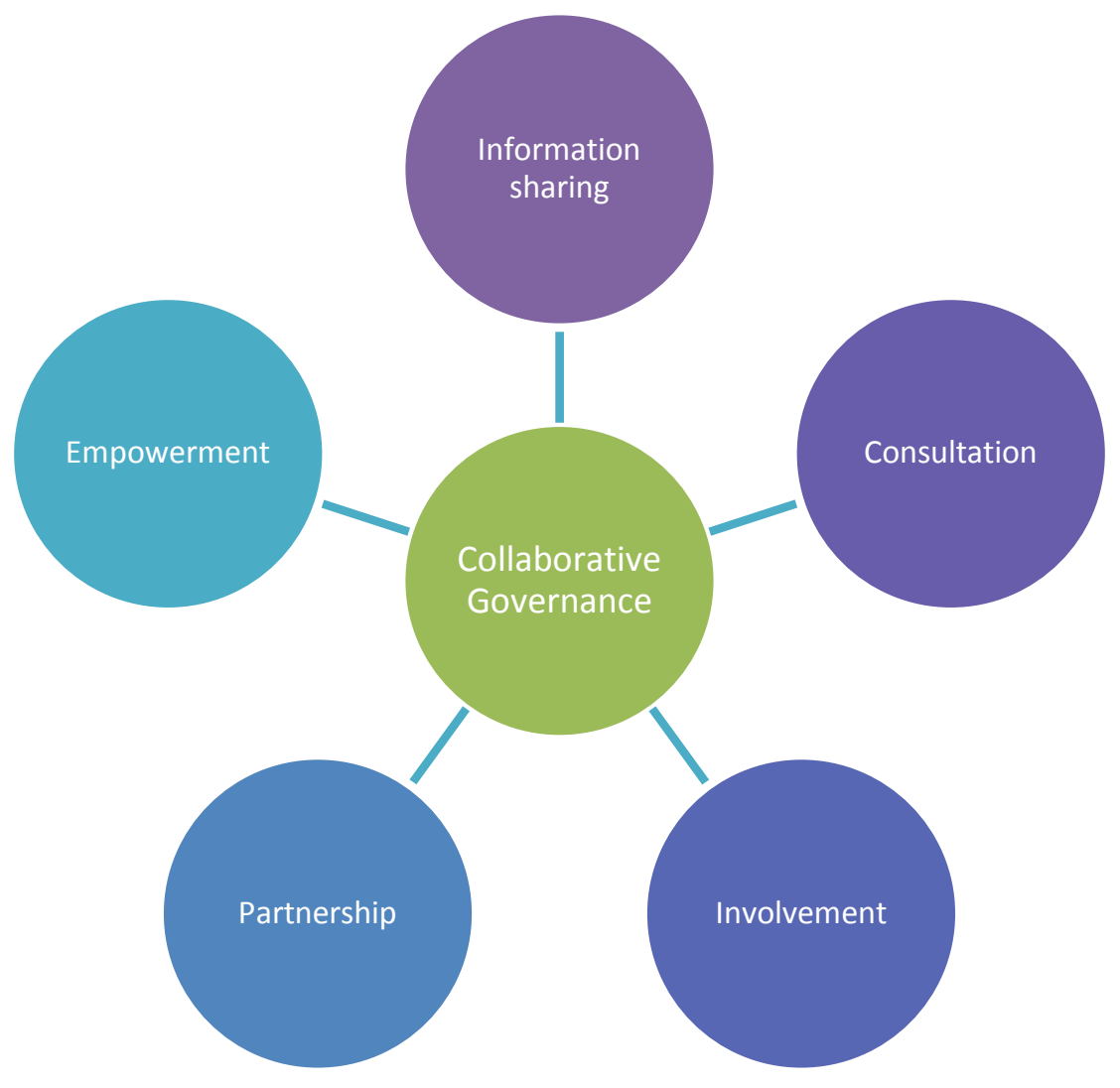

Fig. (1). Categories for good collaborative governance.

Through this classification process it has been possible to review and then identify critical incidents and events, in relation to governance developments. These events are those which have been identified as the catalysts for subsequent substantial organisational change and development. They are characterised by both an increased volume of management 
activity in the food banks and a series of significant incidents over a short time period, leading to new governance arrangements. Three such sets of events have been identified at five year time intervals. These are described in the following Narrative section and summarised in the subsequent Table (1). below. This process of selection has enabled the structuring of the following narrative in this article. After the longitudinal case study account the Discussion and indicative findings draw again on the Collaborative Governance framework for the purposes of evaluation, and the setting out of possible future scenarios for service planning purposes.

\section{CASE SUDY: NARRATIVE}

\subsection{Stage One: 2006}

Conceived in 2003, piloted in 2004, by December 2006 the Winchester Basics Bank had completed its induction stage, and become routinized in its service delivery and organisational practices. It was open twice a week for five hours on Tuesday and Friday, in order to ensure provision prior to the weekend and across the week. Client referrals from approved local agencies appeared to be stabilising at around 7-8 per day. Accordingly, 600 per annum seemed a reasonable calculation for maximum demand and the Basics Bank itself was regarded as most likely a temporary expedient. The same sense of reaching a plateau applied to the number of referral agencies $(n=c .25)$, which were recruited principally from the local churches, hostels, health centres and statutory social care agencies. Once vetted these acquired the title of 'Partners' for the Basics Bank. Provision for clients was evenly balanced between clothing and food, with the Basics Bank determined to ensure that any referred caller could obtain a full outfit for such purposes as a job interview or social housing application. Premises were in the previously disused basement of a building off the main high street in the city centre and out of view from passing traffic and shoppers. Food provision took two forms: a five day package for most callers, but three days of items for those with no fixed abode and no means of food storage or fixed cooking facilities. Supplies were often short so the contents of the packages were often determined simply by what was available on the shelves in the cellar. All donations were accepted and distributed, subject to being within the suppliers' prescribed dates for use. Volume was seen as key, with pasta as the staple item supplemented by tinned fish, processed meats, soups and baked beans. Nutritional value was severely limited.

At the end of 2006 Basics Bank governance was in place. It was now a registered charity with six trustees, having started as a steering committee of the Winchester Churches Together (CT) group. All of these persons were also volunteer helpers at the Bank. All were also retired women, except the Treasurer. The average age was well into the mid-sixties, as was that of the 16 persons on the active volunteers' list. Volunteers helped out on a half day sessional basis. Most sessions were covered by a volunteer, but not all. For security purposes there was a direct alarm link to the local police station from the Bank's below ground and rather damp premises.

In terms of the endorsed criteria for collaborative governance [13], as summarised in Fig. (1) above, the management roles and relationships were limited. Information sharing, in respect of common issues at this time, was entirely for operational purposes. Winchester's was the first food bank to be set up outside of the major cities of Portsmouth and Southampton in the county of Hampshire, and it copied the latter's SCRATCH food bank model for the design of its referral forms and paper entry system. Callers did not even have to provide postcodes and anonymity was the overriding concern. Accordingly, consultation in terms of feedback from clients was at best anecdotal and largely shaped by any responses to the overtly Christian messages of the wall posters, advertisements and hand out leaflets on display around the basement walls. A linked church book shop was in operation on the floor above the Bank. The first Winchester Basics Bank annual reports for 2005-2006 gave the figures for referral agencies, but only otherwise distinguished need by the categories of families and single adults.

Involvement by the community came down to contributions by a few altruistic individuals and informal groups. The generosity of local supermarket manager was crucial in ensuring adequate supplies; and so too was the tolerance of the neighbouring landlord, when faced with the used syringes and multiple beer cans abandoned by the Bank's clients on his door step. In total the regular donors numbered fewer than twenty with only one retail outlet amongst the Basics Bank supporters. At this time, above all else, the vocational involvement of a missional Anglican Minister and local City Council administrator were, literally saving graces: through discreet one off grants, appeals and a brokered supply of logistical resources. In 2006 two long term collection points for donations were established, and an elderly Salvation Army member continued to collect these weekly as she had before 2004, for the Army's own separate emergency aid service for homeless persons.

In 2006 Partnership, the fourth element of collaborative governance, was, however, rather more apparent than 
community involvement, albeit that both were narrowly defined. Right from the beginning the Winchester Basics Bank viewed itself as part of a wider constellation of services for people in urgent need. Its two original instigators were staff of the small church housing association which provided short and mid-term move-on apartments for single men. It was their experience there which led directly to the expressed need for a food and clothing bank to be both identified and communicated to the Churches Together group in 2005. With one of the two pioneers as Basics Bank Chair, it was their influence which led to the decision, in 2006, to appoint two qualified co-managers with formal accountabilities and salaries, ending the reliance on the host church's goodwill that characterised the start-up phase. Similarly it was their connections which steered Churches Together members to secure premises in close proximity to the night shelter, a small informal day centre, the drugs users' rehabilitation clinic, emergency duty social work team and community prison. (These were each principal sources for agency referrals to the Bank.)

Almost all the volunteers and trustees were also living in this city centre neighbourhood and came from four of the local churches in this area: Evangelical, Pentecostal, Salvation Army and United Reform. In 2006 these represented less than a third of the Churches Together organisational membership in the Winchester district. The two co-managers worshipped at the two churches which supplied the premises and most of the personnel. The typical target client for the Basics Bank in 2006 was a single rootless man, without employment and a history of drastic relationship breakdowns.

Finally, in respect of Empowerment through shared operational control over service delivery, in 2006 governance of the Winchester Basics Bank registered a nil return. It did its own thing. There were no joint procedures or common criteria with other agencies and service users had no voice. They were only allowed on to the premises singly, and in 2006 the only step forward was to provide some handout information on the opening times of the local Citizens Advice, Employment, Housing and Social Security centres. The year ended with a proposal to provide a display stand with a wider range of agency leaflets and contact points for all the local Anglican parishes.

Overall, Collaborative Governance in 2006 was in its infancy at Winchester Basics Bank. Its strengths lay in its founding connections and core religious membership, although this was still restricted to a proportion of active Christians and could not claim to be truly representative of either the faith or the wider community. Nevertheless the year's events and decisions did see the advent of the service as a formal organisation with executive and legislative features and explicit aims. These aims did not include continued growth.

\subsection{Stage Two: 2011}

In 2011 the national context was that of severe economic pressures in the aftermath of the global banking crisis and a new government in London dedicated to financial probity and control, with a stated manifesto commitment to support what was termed 'The Big Society' [15]. The local context was that of rising unemployment, levels of debt and static public expenditure. For the Winchester Basics Bank it was a period of rapid expansion, on all fronts. For the first time year-on-year referrals to the Basics Bank in Winchester went up by more than 10\% in 2010/2011 - an annual rate of increase that continued to apply until 2016. In 2011 staffing doubled from 2006 levels, with the appointment of an Administrator and a new job description for a single Manager employed on extended hours. The employer now had limited company status and received its first full and detailed independent auditor's examining report. The company was about to acquire a board of ten directors including, for the first time, three men all of whom were in full-time employment. It also included two qualified social workers. In 2011 the formal management meetings stopped taking place in the homes of the trustees.

The rate of increase in referrals was actually being more than matched by the scale of monetary donations. In 2011 the unrestricted funds increased by almost $50 \%$ to a total of just under $£ 30,000$, while expenditure was just double that of 2006 at below $£ 9000$ [16]. This abundance of financial resource triggered the first away day for board members to develop an outline three year strategy and a business plan, with agreed proposals for three days a week opening and a second service outlet. By 2011 the Basics Bank had already moved (in 2008/2009) from it basement home to larger premises, in response to the growing demand, in a residential area on the main bus routes away from the city centre. This venue was now already rapidly turning out to be insufficient to meet the changing volume and cross generational profile of callers. 2011 was proving to be a year of unprecedented pressures for the Bank as a result of the economic downturn.

In terms of Collaborative Governance the year also witnessed fundamental changes. The need to understand the significance of the economic, social and personal pressures in the external environment became paramount. For the first time the expectations of directors extended well beyond just attending committee meetings and signing up for volunteer 
sessions. The last began to diminish in number, although three directors were trained to provide emergency managerial cover. Information sharing meant multiple activities. In small groups board members visited three other food banks, attended local City Council workshops for the independent sector and received a briefing - on such functions as stock control, packaging and volunteer vetting - from the executive of the Trussell Trust. By now this organisation was the largest operator of food banks in the United Kingdom. The past Chair wrote an article for the local newspaper and 2000 brochures were printed. The present Chair provided a carefully considered and scripturally based Reflection for fellow trustees as an aid to identifying the Bank's future mission, and this was followed by the introduction of a regular, professional standard Winchester Basics Bank Newsletter. This detailed both the supply side requirements and the changes in local demand for urgent assistance.

As an independent company with its own sizeable Board of Directors the Basics Bank in 2011 could no longer perceive itself as being simply under the wing of the Churches Together group. It undertook its own first significant consultation exercise. One of the new trustees was charged with interviewing the heads of the key partner agencies. These referral partners were no longer just focused on deviance and delinquency. They now included a number which focussed on domestic matters, including three local childrens' centres, and the charitable 'Friends of the Family' rehabilitation and 'Living at Home' support services. Community involvement was similarly expanding. Volunteer numbers increased to between 40 and 50, and now included non-church goers. Volunteer lunches began as exercises in peer support and community intelligence gathering. Basics Bank stalls were set up at Winchester Cathedral and Night Shelter Festivals. The involvement now incorporated political and corporate interests. The Member of Parliament visited. So too did a well known local Council leader. A cheque came in from a major and well respected high street shop. And more Christian representatives rapidly joined in. The new Chair In 2011 did attend as a worshipper one of the founding group of four churches, but also her local parish church as well. A patron was appointed: a distinguished lay canon from the Cathedral and House of Lords. Most significantly, and for the first time, the largest local Roman Catholic and Non-Conformist (New Frontiers) churches nominated senior congregation members to the expanded Basics Bank board. This now possessed persons from seven churches, but none from the original host Pentecostal Church, the new leadership of which was concentrating now on different social and pastoral needs in the child care sector.

The extended community involvement meant a wider pattern of relationships, and a first experience for the Basics Bank of power sharing. In 2011, and informally at first, Chairs' meetings began with Heads of the Winchester Night Shelter, Keystone Housing, the local Vineyard movement and the purpose built Trinity Day Centre. The latter now had capacity to provide up to 100 lunches per day, drawing on its own horticultural scheme and significantly affecting the pattern of afternoon calls to the Basics Bank reception as a result. Such developments and the escalating demand meant new partnerships had to be forged with both donors and suppliers. Three major supermarkets were contacted and agreed to provide either dedicated collection points or times. Over 40 churches and schools agreed to contribute via Harvest Festival services and assemblies, with Basics Bank volunteers on rotas for collection and shelf stacking purposes. A new DVD was produced with briefing notes for external presentations by directors at the likes of the Rotary Club, the local University Students' Union, and Methodist Hall.

The overall effect was for the Basics Bank to start to undertake health education activities, particularly at this stage with its active supporters. And the growing awareness of healthy dietary needs in a time of general economic decline fed into the daily practice of donations and service delivery. Food collection points now had lists of recommended product types including such as nutritious breakfast cereals and snacks, while priests from the pulpit urged congregations to give 'quality' products and not just the cheapest ones.

By 2011 the changing features of Collaborative Governance at the Winchester Basics Bank had produced a visibly different appearance at its premises. A single and simple image of loaves and fishes on the front counter sought to convey a message of shared resources for all, replacing past denominational material. The same applied to comprehensive sets of leaflets in the waiting area, which included much more information on State provided social security payments and housing advice. Often two volunteers would be present, and there was even a parking space and a toilet available for callers. The front of house was a large glass window with the Winchester Basics Bank title clearly visible; no longer a temporary back street signing as before. And clients could now browse and select freely from the various marked clothing sections. These occupied about a third of the downstairs area and were increasingly dominated by children's items and basic hygiene products, reflecting the survival struggles of an increasing number of local families. This trend was also evident in the board of directors which, in 2011, now included its first head teacher from a primary school. 


\subsection{Stage Three: 2016}

Two more senior educational representatives had been added to what had become a 12 member board by the beginning of 2016, as the chair role passed between individuals with director level backgrounds in the film industry and Probation Service. The latter attends the Roman Catholic Church, as do two other directors, one of whom is Polish and a local sports centre manager. The post-2011 created role of Basics Bank President is also occupied by the senior Roman Catholic priest in the city, and the Annual General Meeting is held in his church. For the Polish director, as for a number of others now serving as trustees, church attendance is irregular. At the beginning of 2016 the Board was evenly balanced in terms of gender and retirees versus employed personnel. The last included individuals from the food industry, finance and consultancy, with the newest recruit in mid-2016 being a current university Dean of Faculty. A prayer is still said at the start of meetings, and at the beginning of each opening day, but some are now uneasy with its unstructured format. The number of volunteers has doubled since 2011 and they now come from all walks of life.

A local Anglican curate provided the summing up in 2015 of the local stakeholder workshop convened by the Basics Bank, after it formally commissioned research designed to obtain views on the priorities for future development from a purposive sample of service users. Their interview responses highlighted the need for more locally accessible, low cost and good quality food outlets in the poorer areas of the city; and the costs in terms of distance and delay of having to go to so many different and disparate welfare agencies in the context of what were perceived as increasingly restrictive benefit entitlements. The curate talked of the importance of valuing Dignity for both communities and individuals. The research findings and workshop report were widely disseminated [17].

A year later, at the follow up workshop on Food Poverty, also principally funded by the City Council, the closing contributions of executive and non-executive members of the local authority concentrated on the distinctive economic as well as social value to Winchester of becoming entitled 'A Sustainable Food City' [18]. There were seven Winchester Basics Bank directors at the first session and just an ex- Chair and ex-trustee at the second. No church representatives, as such, were present. The slogans of several new and local charitable initiatives were, however, much in evidence: 'Incredible Edible', 'Taste of the South', 'Fruits of Fulflood', 'LEAF' and 'Sustain'. All concentrated on the health and environmental benefits of improved nutrition. Together they looked for material support from the City Council following its decision in January 2016 to undertake the preparatory work 'for a food strategy and action plan' [19]. Prevention of food poverty, healthy (organic) eating, domestic horticulture and self-sufficiency were their themes.

In contrast to its new charitable counterparts in 2016 the Winchester Basics Bank remains completely independently funded. Its total funds exceed $£ 40000$, and there have been several four figure individual donations. A monthly giving scheme operates with Gift Aid tax relief. Invitations to accept a service level agreement from the County Council, and an affiliation to the Trussell Trust and its social skills based More Than Food programme have been declined. In 2015 and 2016 well over 3000 people have been referred to the Winchester Basics Bank by more than 50 partner agencies, including more than 1200 children in each year. A holiday meals scheme has operated in the school summer vacations. The annual proportion of total annual referrals as one-off urgent requests, however, has remained largely unchanged at between 10-20\% since 2005-2006. Four visits per annum to the Basics Bank continues to be the maximum for clients, across what are now its four service outlets across the city, the suburbs and - via volunteer transport - the rural parishes. All of these locations now supply the Winchester Basics Bank with volunteers, trustees and donations. Around 60 events per annum are held to raise funds for the Basics Bank, mostly by primary schools. The Basics Bank itself now has a staff complement which includes an Operations and a Service Manager, a storeman, a Company Secretary and a work experience trainee. There are around 90 volunteers: three per half day session. These do not now include the directors, each of whom is fully occupied with a designated area of executive responsibility and expertise (e.g. Volunteers, Health and Safety, Communications, etc).

In 2016 the Winchester Basics Bank is back focussing on its core business of supplying subsistence to those who are hungry and in urgent need. It does try to shape food donations and diets by providing details of nutritional food shortages at its collection points, and healthy cooking menus on request to callers. But it still accepts everything. Chocolate and biscuits abound. Sugar filled tins of baked beans, cereal packets, and processed meats and fish are the most popular items. Fresh food is now available but very limited. Pragmatic pastoral care still appears to conquer pure public health priorities, despite the increased awareness of the latter. Now the large majority of referrals are for low wage or unemployed family households: around 70\% in 2016 coming through the housing and welfare agencies of government, more than double the level of 2011. And, as has been confirmed nationally, around $40 \%$ of these emanate from delayed or transitional State benefit payments [20]. 
In respect of the five components of collaborative governance 2016 represents another significant sea change in terms of organisational development. The preceding Narrative account indicates that the Food Bank, after ten years, is now perceived by itself and by other agencies as a reliable and respected source of baseline data. The sharing of this information, through both its detailed audit and annual reports and, grant and university supported research, in conjunction with the Food Up Front research charity, underpinned the two workshops, providing a secure basis for consultation, the second key characteristic of collaborative governance. This helped in enabling elected representatives and their officers to engage with the wider subject food poverty. The Winchester City Mayor actually introduced the October 2016 workshop. Unpacking the data by neighbourhood, age groups and socio-economic status contributed to the growing specialisation of independent sector inputs. Involvement with the community and its concerns, as a result, has moved to a different democratic level: local, political, civil society oriented and public health based. It now embraces advocacy and social action. Explicitly employing the intelligence and experience of the Winchester Basics Bank, a major social enterprise entitled Winchester Action on Climate Change has incorporated food poverty into its campaign for a greener environment and better public health. It prepared a briefing paper for City Council on Sustainable Food Cities at the beginning of 2016 [21].

These developments in the Involvement, Consultation and Information functions of Collaborative Governance have actually led to a diminution of the Winchester Basics Bank's position in respect of Partnerships. As its directors have returned its focus in 2016 to the core business of hunger and immediate urgent need so the relationships between churches have resumed. The new service outlets, accordingly, are all in church premises: each one starting in an evangelically oriented setting as occurred in 2006. With the supermarket Tesco's backing the regional Fareshare scheme is now an important, necessary and reliable supplier, and a required part of joint delivery arrangements with the other major supermarkets. Similarly membership of the new national Network of Foodbanks is seen as a source of shared learning on operational matters. The City Council's Strategic stance also matters. It is reported at board meetings. The 2016 review of the four Winchester Diocese's strategic aims, which include proposals for the expansion of churches' social enterprises and stewardship roles, has not. The local authority and civil society emphasis on specialist inputs, accordingly, seems to be more influential than the Churches Together and Winchester Deanery developments for broad based missional pastors and ambassadors. The Vineyard Church now operates a direct access clothing store. The Basics Bank no longer does. The New Frontiers Church runs a soup kitchen. The Salvation Army still supplies bedding. The largest Anglican church hosts both a debt counselling and advice charity as well as the local branch of Street Pastors. It provides an emergency payment facility too. The Emmaeus Community continues to expand its sheltered employment and residential services. Each has its niche.

Table 1. Schedule of critical incidents.

\begin{tabular}{|c|c|c|}
\hline $\begin{array}{l}\text { Time Interval } \\
\text { Periods }\end{array}$ & Key Events & Organisational Structure \\
\hline $2005-2006$ & $\begin{array}{l}\text { - Churches Together initiative and endorsements } \\
\text { - Wall displays of Christian literature } \\
\text { - Referrals from local community contacts/donors in city } \\
\text { centre (n=25)incl. one supermarket } \\
\text { - Evangelical church led Volunteers (n:16) and Trustees } \\
\text { recruitment with start-up grants (£6k) } \\
\text { - City Church basement premises secured } \\
\text { - Co-managers appointed } 2 \text { days per week }\end{array}$ & $\begin{array}{l}\text { New charity } \\
\text { - with new group of } 10-15 \text { volunteers } \\
\text { - home based meetings and skittle alley socials }\end{array}$ \\
\hline $2010-2011$ & $\begin{array}{l}\text { - First mid-term strategy } \\
\text { - Annual business plan } \\
\text { - Chair's leadership 'Reflections' review } \\
\text { - Register of c. } 40 \text { plus partner agencies } \\
\text { - Publicity stand and formal presentations } \\
\text { - Local authority service agreements (declined) } \\
\text { - Single reception image for shared resources }\end{array}$ & $\begin{array}{l}\text { Limited company } \\
\text { - } 10 \text { Directors, with separate manager and administrator, and } \\
\text { offsite committee and 'Homelessness' charities' meetings } \\
\text { - 30-40 volunteers }\end{array}$ \\
\hline
\end{tabular}


(Table 1) contd....

\begin{tabular}{|c|c|c|}
\hline $\begin{array}{l}\text { Time Interval } \\
\text { Periods }\end{array}$ & Key Events & Organisational Structure \\
\hline $2015-2016$ & $\begin{array}{l}\text { - Annual General and Board Meetings in Roman } \\
\text { Catholic and Vineyard churches } \\
\text { - Staff and volunteers teams }(\mathrm{n}=90) \\
\text { - Independent audit and } £ 40 \mathrm{k} \text { income } \\
\text { - First external research commissions } \\
\text { - Regular corporate contributions include } 3 \text { supermarkets } \\
\text { - C. } 60 \text { partners and fundraisers } \\
\text { - } 70 \% \text { plus referrals from district wide state } \\
\text { - agencies } \\
\text { - Gateway information on social welfare and nutrition } \\
\text { benefits } \\
\text { - Named agency for public health improvements }\end{array}$ & $\begin{array}{l}\text { Stakeholder social enterprise } \\
\text { - } 12 \text { Directors, majority with senior management backgrounds, } \\
\text { mixed gender } \\
\text { - Co-convenor of Health and Wellbeing events }\end{array}$ \\
\hline
\end{tabular}

\section{DISCUSSION}

The preceding paragraph illustrates how the faith based contribution in relation to what is now termed 'food poverty' has reverted almost exclusively to that of a safety net service, albeit with specialist roles and responsibilities. It also indicates how this contribution has helped pave the way for 'food poverty' itself to be acknowledged and recognised as a social policy issue, requiring public health responses. In terms of Collaborative Governance these trends have been aligned with the progression of the Winchester Basics Bank towards wider and more flexible membership at first tier management levels and extended geographical and cultural reach. It has, however, also remained strictly (but more flexibly) Christian in the composition of its trusteeship and directors, and although the new social enterprises and local authority inputs have influenced the Basics Bank's role, its direction has remained much more dependent on Biblical sources than any secular planning documents. The first of these sources seem to supply the essential common ground in validating the safety net role through different expressions of the 'Good Samaritan' story across the alternative denominations.

The different denominational roles are also of interest in this case study and may be indicative for other Christian social enterprise developments. For the Winchester Basics Bank, the early years witnessed the more evangelical community churches in the forefront in identifying local need, providing innovative energy and start up resources, including volunteers, premises and the first supervisors. As the service expanded and became a more complex formal organisation with a staff group, differentiated and trained volunteers, and a sizeable board of directors, however, it was the churches with the more established institutional and physical structures and external agency relationships, that came to the fore: in particular, the Roman Catholic and Vineyard churches.

As a result, in the years after 2011 the emergent social enterprise was in a form which aped a corporate enterprise, and only reverted to its grassroots origins through semi-autonomous distributed local church outlets, as the public health agenda associated with food poverty engendered new agency initiatives across the wider civil society of Winchester. This agenda now sees presenting public health problems of such as depression, obesity and diabetes directly linked to the likes of vertical gardens and new allotments. Local debates and national articles include concerns about the relationship between food banks and levels of obesity in the lower socio-economic population categories, linked to the questionable calories' content of typical packages for the banks' clients [22].

In relation to the main principles of Collaborative Governance it is clear that each has applied in the development of the Winchester Basics Bank. In terms of Information Sharing, for example, the review of referral profiles undertaken each year for the Chairs' annual reports has contributed to the database which underpins Churches Together support for the growing network of residential and day care facilities for homeless and rootless persons. Communication between the Winchester Nightshelter, Trinity Centre and the Emmaeus residential community is stronger as result, including regular ad hoc meetings now between the chairs of each. Similarly, the emerging Partnerships have led to exercises in joint priority setting, of which some of the new charitable initiatives, such as Incredible Edible, are the outcome. The last reflects the findings of the 2015 stakeholder workshop convened by the Basics Bank, which put more community education at the top of the list for future actions [17].

The range of new and specialised charitable initiatives - beyond the Basics Bank - to promote local health and wellbeing, also point to its limitations in terms of the collaborative governance dimension of Empowerment. Its single faith status does signify only restricted stakeholding community proprietorship and this has been evident in its exclusion from both the expansion of services to address food poverty and the strategic planning by the local authority. The latter seems better placed still to undertake this function. 
By contrast, as a faith based agency, the Basics Bank scores particularly highly in respect of Involvement and Consultation. Most obviously, it has demonstrated its capacity to access and expand philanthropic resources, as its income has increased tenfold in as many years. The same applies to volunteer recruitment. And it has achieved and retained public trust and confidence. This confidence has not simply come from sympathetic individuals or Christian groups, but also from major commercial enterprises and people of other faiths; and, in respect of referral agencies, no faith at all. In Winchester at least, the integrity of the values espoused by the Christian church are accepted, and this then is perceived to provide a sound platform for public health oriented actions that go beyond traditional pastoral care by individual clergy. Table (2) below provides an indication of the intended and possible public health benefits that can arise from good practice in the different dimensions of collaborative governance at a food bank, based on the Winchester experience.

Table 2. Collaborative governance and public health.

\begin{tabular}{|c|c|c|}
\hline $\begin{array}{c}\text { Collaborative } \\
\text { Governance - } \\
\text { Dimensions } \\
\text { Barbazza and Tello } \\
\text { (2014) }\end{array}$ & $\begin{array}{l}\text { Component Features: Priorities } \\
\text { (e.g.s only) }\end{array}$ & $\begin{array}{c}\text { Public Health Benefits: Identified as Targets in 2015/16 Stakeholder } \\
\text { Workshops }\end{array}$ \\
\hline Joint information & $\begin{array}{l}\text { Shared local 'soft' intelligence and Office } \\
\text { of National Statistics' data }\end{array}$ & Pinpointing streets and neighbourhoods with nutritional deficits \\
\hline Consultation & Confidentiality in private matters & $\begin{array}{l}\text { Anonymous access for destitute and marginalised persons to primary health } \\
\text { and pastoral services }\end{array}$ \\
\hline Involvement & $\begin{array}{c}\text { Access to philanthropic sources of income } \\
\text { and investment }\end{array}$ & $\begin{array}{c}\text { Co-contributions through local benefactors and sponsors via personal values } \\
\text { and stories of health and housing losses }\end{array}$ \\
\hline Partnership & Participation in priority setting & $\begin{array}{l}\text { Client survey inputs to new healthy dietary, horticultural and culinary } \\
\text { projects }\end{array}$ \\
\hline Empowerment & Full or partial community ownership & $\begin{array}{l}\text { Local health education initiatives underpinned by spiritual values and } \\
\text { recruitment of local service champions }\end{array}$ \\
\hline
\end{tabular}

\section{CONCLUSION}

In summary: this study has described how a local bank has developed its management structures and processes over the past decade and become a social enterprise successfully operating to a model of Collaborative Governance. Being defined in this way has enabled it to move beyond its original urgent pastoral care remit towards that of public health objectives in relation to food poverty. Retaining a faith based commitment throughout the period has had important benefits in terms of resources and, despite some limitations in relation to external stakeholders and their agendas, this has continued to achieve credibility with both clients and local communities. As a result, this indicative study offers encouragement for the emerging mixed economy of social security and welfare, and the location of public health within elected Councils, where local planning authorities can be viewed as more readily able to mobilise civil society energies for improved public health than national health care institutions.

\section{ETHICS APPROVAL AND CONSENT TO PARTICIPATE}

Not applicable.

\section{HUMAN AND ANIMAL RIGHTS}

No Animals/Humans were used for studies that are base of this research.

\section{CONSENT FOR PUBLICATION}

Not applicable.

\section{CONFLICT OF INTEREST}

The author declares no conflict of interest, financial or otherwise.

\section{ACKNOWLEDGEMENTS}

Thanks go to all the fellow travellers in relation to the local food bank story, and in particular, Basics Bank trustees and volunteers, Food Up Front, the Hildon, Scheckter, Trussell and Bill Sargent Trusts, Winchester City Council, Primary Care Matters and colleagues in the Health and Wellbeing Group at the University of Winchester. 


\section{REFERENCES}

[1] Office for National Statistics. Annual mid-year estimates. Statistical Bulletin. http://www.ons.gov.uk accessed 12 July 2016.

[2] McCarthy K. Food banks in Hampshire. Winchester, UK: Community Action Hampshire 2012.

[3] Lambie H. The Trussell Trust Foodbank network: exploring the growth of foodbanks across the UK. Coventry, UK: Coventry University 2011.

[4] Oxfam Walking the breadline: the scandal of food poverty in 21st century Britain Church Poverty in Action report. Oxford: Oxfam 2013.

[5] Forrest A. Muslim groups putting their faith in food banks to tackle poverty. 2014. The Guardian; 2 April

[6] Curtis A. Evaluation briefing for the Food Network's 'More than Food' programme. Salisbury, UK: Trussell Trust 2016.

[7] Downing E, Kennedy S. Food Banks and Food Poverty. London: 2014. House of Commons Briefing Paper SNO 6657

[8] Mayfield S. Winchester Basics Bank Letter of application. London: Hilden Trust 2014.

[9] Dobson J, Papworth R. Between a rock and a hard place. Winchester, UK: The Bill Sargent Trust 2014.

[10] Ralph N. Winchester Social Enterprises. Hayes Conference Centre. Swanwick, UK. 2016.

[11] Dakin T. Deanery Mission Action Planning. Winchester, UK: Winchester Diocese 2014.

[12] Action Plan 2016-2018. Winchester, UK: Winchester City Council 2016.

[13] Barbazza E, Tello JE. A review of health governance: definitions, dimensions and tools to govern. Health Policy 2014; $116(1)$ : 1-11. [http://dx.doi.org/10.1016/j.healthpol.2014.01.007] [PMID: 24485914]

[14] Meads G, Russell G, Lees A. Community governance in primary health care: towards an international Ideal Type. Int J Health Plann Manage 2016.

[http://dx.doi.org/10.1002/hpm.2360] [PMID: 27230589]

[15] Scott M. Reflections on The Big Society’. Community Dev J 2011; 46(1): 132-7. [http://dx.doi.org/10.1093/cdj/bsq057]

[16] Directors' Report and Accounts Financial Statements for 2012. Winchester, UK: The Winchester Basics Bank Ltd 2013.

[17] Mayfield S, Meads G. Dignity and Diversion A working paper. University of Winchester, UK 2016.

[18] Andrews T. Sustainable Food Cities Proceedings of Sustainable Food Stakeholder Event. Winchester, UK; 2016.

[19] Appleby E. Sustainable community strategy and corporate business plan. Winchester, UK: Winchester City Council 2016.

[20] Loopstra R, Fledderjohan J, Reeves A, et al. The impact of benefit sanctioning on food security: a dynamic cross-area study of food bank usage in the UK. 2016. Sociology Working Papers No. 2016.

[21] Holloway C. Food Strategy: scoping review. Winchester, UK: Winchester Action on Climate Change 2016.

[22] Aitken R. Food banks: the unpalatable truth. 2016. Daily Telegraph, 16 November

CC 2017 Geoffrey Meads.

This is an open access article distributed under the terms of the Creative Commons Attribution 4.0 International Public License (CC-BY 4.0), a copy of which is available at: https://creativecommons.org/licenses/by/4.0/legalcode. This license permits unrestricted use, distribution, and reproduction in any medium, provided the original author and source are credited. 